\title{
Fractionation of Inorganic Phosphorus and Aluminum in Red Acidic Soil and the Growth of Camellia oleifera
}

\author{
Jun Yuan, Liyuan Huang, Naifu Zhou, and Hui Wang \\ Key Laboratory of Cultivation and Protection for Non-Wood Forest Trees, \\ Ministry of Education, Central South University of Forestry and Technology, \\ Changsha, Hunan 410004, China
}

\section{Genhua Niu ${ }^{1}$ \\ Key Laboratory of Cultivation and Protection for Non-Wood Forest Trees, Ministry of Education, Central South University of Forestry and Technology, Changsha, Hunan 410004, China; and Texas A\&M AgriLife Research, Texas A\&M University System, 1380 A\&M Circle, TX 79927}

Additional index words. Camellia oleifera, aluminum-bound, fractions, Al-P interaction

\begin{abstract}
Aluminum (Al) toxicity and phosphorus (P) deficiency are two crucial factors limiting the production of Camellia oleifera, which is grown commercially in red acidic soils in Southern China. The current study characterized the different forms of $P$ and $A$ in the red acidic soils of $\boldsymbol{C}$. oleifera plantations. Soil and plant tissue samples taken from 32 Camellia plantations across Hunan province were analyzed. Furthermore, a pot experiment with nutrient solutions of different $\mathrm{Al}$ and $\mathrm{P}$ contents was carried out to investigate $P$ and $\mathrm{Al}$ uptake and their effect on $C$. oleifera growth. The results showed that the $P$ content extracted by $\mathrm{NaOH}(\mathrm{Fe}-\mathrm{P})$ was the highest in all types of soil samples (rhizosphere, 0-20 cm, and 20-40 cm zones), followed by $\mathrm{P}$ extracted by $\mathrm{NH}_{4} \mathrm{~F}$ (Al-P), $\mathrm{H}_{2} \mathrm{SO}_{4}(\mathrm{Ca}-\mathrm{P})$, and $\mathrm{Na}_{3} \mathrm{C}_{6} \mathrm{H}_{5} \mathrm{O}_{7}(\mathrm{O}-\mathrm{P})$. $\mathrm{HCl}$ (In-Al), $\mathrm{NH}_{4} \mathrm{Ac}(\mathrm{Ha}-\mathrm{Al})$, and $\mathrm{Na}_{4} \mathrm{P}_{2} \mathrm{O}_{7} \cdot \mathbf{1 0 H}_{2} \mathrm{O}$ (Or-Al) extracted $\mathrm{Al}$ were the main forms and accounted for $22.8 \%, 23.1 \%$, and $23.8 \%$ of total $\mathrm{Al}$, respectively. $\mathrm{KCl}$ extracted $\mathrm{Al}(\mathrm{Ex}-\mathrm{Al})$ contents in the rhizosphere, $0-20 \mathrm{~cm}$, and $20-40 \mathrm{~cm}$ soil zones were $4.78,4.86$, and $4.59 \mathrm{mg} \cdot \mathrm{kg}^{-1}$, respectively. $P$ contents in roots, young leaves, and old leaves were $0.80,0.82$, and $0.64 \mathrm{mg} \cdot \mathrm{kg}^{-1}$, respectively. The highest Al content of $11.35 \mathrm{~g} \cdot \mathrm{kg}^{-1}$ was found in the old leaves, followed by roots and young leaves. Correlation analyses revealed that $P$ in roots was positively associated with available $P$ (AP) and Al-P in rhizosphere. $\mathrm{P}$ in roots and young leaves also had a positive correlation with Ex-Al, whereas Al in old leaves was positively correlated with In-Al and total Al. Significant correlations between Al-P, Ex-Al, and AP were detected. The pot experiment indicated that adding $\mathbf{A l}$ or $\mathbf{P}$ alone increased plant growth and Al or $\mathbf{P}$ uptake, respectively. When adding both $A I$ and $P$, significant synergistic effect was found. These results suggest that $\mathrm{Al}$ is beneficial to $C$. oleifera, which may be the adaptive mechanism of C. oleifera to use insoluble Al-P in red acidic soil.
\end{abstract}

Acidic soils account for $30 \%$ of the world's total land and as high as $50 \%$ of the arable land (Kochian et al., 2004). In these low $\mathrm{pH}$ soils, $\mathrm{P}$ is easily fixed by clay minerals and becomes unavailable for root uptake. On the other hand, Al is solubilized into ionic forms, which are easily absorbed by plants, especially when soil $\mathrm{pH}$ falls below 5 (Zheng, 2010). Early studies about acidic soils focused on Al toxicity (Kochian, 1995). High Al content in acidic soils inhibits root growth and consequently affects whole plant growth and development (Yi et al., 2010; Zheng, 2010). The lack of essential mineral nutrients has also been attributed to acid soils

Received for publication 7 June 2017. Accepted for publication 18 July 2017.

This study was cofunded by the National Natural Science Foundation of China (No. 31400582) and the Talent Introduction Foundation of Central South University of Forestry \& Technology (2013RJ002). ${ }^{1}$ Corresponding author. E-mail: gniu@ag.tamu.edu.
(Kochian et al., 2004). P is the most important limiting nutrient in acid soils because of Al-oxyhydroxide fixations that lead to low $\mathrm{P}$ solubility and not readily available for root uptake (Zheng, 2010). Thus, Al toxicity and P deficiency are two interrelated factors limiting plant growth and crop production in acidic soils (Barcelo and Poschenrieder, 2002; Yu et al., 2016). The concurrence of high $\mathrm{Al}$ (Al toxicity) and low $\mathrm{P}$ (P deficiency) has been widely investigated for many plant species (Liao et al., 2006; Maejima et al., 2014; Zheng, 2010). Aluminum toxicity is closely associated with $\mathrm{P}$ deficiency, and $\mathrm{P}$ may be an effective nutrient facilitating the detoxification of excess $\mathrm{Al}^{3+}$ under low $\mathrm{pH}$ (Maejima et al., 2014). Many studies on $\mathrm{Al}$ tolerance mechanisms have shown that Alinduced root organic acid (OA) exudations can exclude toxic $\mathrm{Al}$ and/or detoxify $\mathrm{Al}$ internally (Kochian et al., 2004; Zheng, 2010). OAs can decrease the uptake of free $\mathrm{Al}$ by chelating $\mathrm{Al}$ and release $\mathrm{P}$ from $\mathrm{Al}$ fixation (Liao et al., 2006; Ligaba et al., 2004). Iqbal (2014) demonstrated that lowmolecular weight OAs can detoxify $\mathrm{Al}$ in the soil and improve $\mathrm{P}$ nutrition of plants. In addition, a study on Oryza sativa found that low $\mathrm{P}$ enhanced $\mathrm{Al}$ tolerance because of lower phospholipid and pectin concentrations in the roots instead of OA secretions (Maejima et al., 2014). Different plant species are likely to employ different Al tolerance mechanisms and enact different forms of interaction with mineral nutrients such as $P$.

$\mathrm{P}$ is a major limiting nutrient of crops mainly because of its slow diffusion and high soil fixation especially in acidic soils by $\mathrm{Al} / \mathrm{Fe}$ oxides and hydroxides (Shen et al., 2011). The availability of $\mathrm{Al}$ and $\mathrm{P}$ depends on the distribution of different forms of $\mathrm{Al}$ and $\mathrm{P}$ in the soil solution. Álvarez et al. (2012) found that labile $\mathrm{Al}$ was dominated by $\mathrm{Al}-\mathrm{OH}$ complexes, which are considered toxic but at a lower level than $\mathrm{Al}^{3+}$. Li et al. (2015) found that fertilization significantly increased the accumulation of extractable inorganic $\mathrm{P}$ fractions. Meanwhile, the cation of $\mathrm{P} / \mathrm{Al}^{3+}$ nutrition can lead to detoxification with the exogenous nutrition thresholds at $\mathrm{P} / \mathrm{Al}^{3+} \geq 4.4$ (Liu et al., 2014). It is important to characterize the different forms of $\mathrm{P}$ and $\mathrm{Al}$ of a specific plant-soil combination.

Camellia oleifera is an important woody plant that has been cultivated in Southern China for more than 2300 years for its edible oil (Zhuang, 2008). C. oleifera trees are typically grown in red clay soil where $\mathrm{P}$ mainly presents as bound phosphates (Zhuang, 2008). Their root exudations, such as citric acids, can significantly increase to enhance $\mathrm{P}$ mobilization in response to deficiencies (Yuan et al., 2013a). Chen et al. (2008) showed that $C$. oleifera accumulated more than $13,500 \mathrm{mg} \cdot \mathrm{kg}^{-1} \mathrm{Al}$ in the old leaves, and seemed tolerant to $\mathrm{Al}$ toxicity and $\mathrm{P}$ deficiency. Addition of $\mathrm{AlPO}_{4}$ in soil increased the $\mathrm{P}$ content in $C$. oleifera plants and enhanced plant growth (He et al., 2010; Yuan et al., 2013b). To date, little information is available about red clay soil fractionations of $\mathrm{Al}$ and $\mathrm{P}$ and whether the Al-P is absorbed by $C$. oleifera. The objectives of this study were to characterize the $\mathrm{Al}$ and $\mathrm{P}$ forms and uptake and their interactions on plant growth of $C$. oleifera in acidic soils.

\section{Materials and Methods}

Soil and plant tissue samples. In China, $C$. oleifera is primarily cultivated in the red acidic soils of Hunan province. Thirty-two plantations with established mature stands of C. oleifera forests across the province were identified and sampled (Fig. 1). At each site, five medium-sized trees were selected for sampling. Soil samples of $0-20 \mathrm{~cm}$ and 20-40 cm zones were collected from four spots (one each at east, south, west, and north directions) at $1.0 \mathrm{~m}$ away from the tree trunks. The collections from each tree were pooled and then quartered for a sample of up to $1 \mathrm{~kg}$. Rhizosphere soil samples were taken by collecting the soil adherent to nonwoody 
feeder roots. The $\mathrm{pH}$ of the soil samples was 3.6-4.9. At the same time, $5 \mathrm{~g}$ of the feeder roots were taken. Forty young (the upper third leaves) and old leaves (the bottom fifth leaves) were collected from the four directions of each tree.

Analysis of $P$ and Al contents in plant tissues. The plant materials (leaves or roots) were rinsed thoroughly in tap water and then in distilled water. After the wash, the samples were dried in an oven at $105{ }^{\circ} \mathrm{C}$ for $30 \mathrm{~min}$ and then at $60{ }^{\circ} \mathrm{C}$ for $24 \mathrm{~h}$. The dried plant materials were ground and digested with $\mathrm{H}_{2} \mathrm{SO}_{4}+\mathrm{H}_{2} \mathrm{O}_{2}$ (EasyDigest 40; AMS, Rome,
Italy). Al concentration was determined by means of aluminon (Nieuwenburg and Uitenbroek, 1948). P concentration was determined using a discrete auto analyzer (Smartchem 200; Westco Scientific Instruments, Rome, Italy) after the malachite green oxalate method. All measurements were carried out in triplicate.

Fractionation of soil inorganic $P$. All soil samples were air-dried and ground manually. Fractionation of soil $\mathrm{P}$ was determined by the sequential extraction procedure outlined by Chang and Jackson (1957) as follows: Al-P $\left(0.5 \mathrm{~g}\right.$ soil $\left.+10 \mathrm{~mL} 0.5 \mathrm{~mol} \cdot \mathrm{L}^{-1} \mathrm{NH}_{4} \mathrm{~F}\right)$, Fe-P

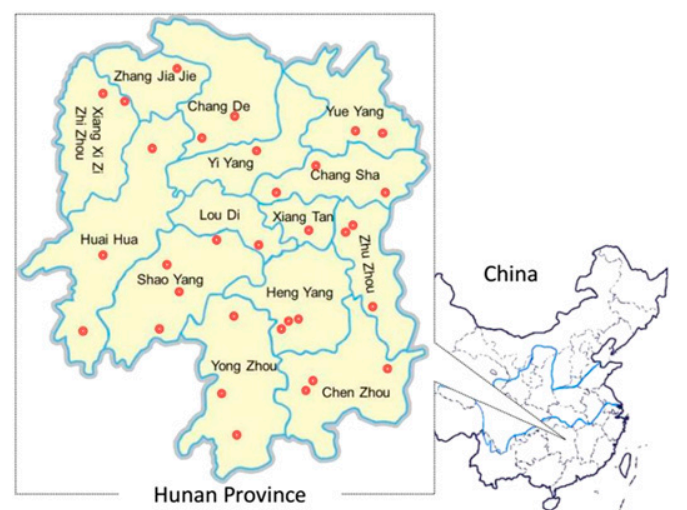

Fig. 1. Sampling sites. (the residual $+10 \mathrm{~mL} 0.1 \mathrm{~mol} \cdot \mathrm{L}^{-1} \mathrm{NaOH}$ ), $\mathrm{O}-\mathrm{P}$ (the residual $+10 \mathrm{~mL} 0.3 \mathrm{~mol} \cdot \mathrm{L}^{-1} \mathrm{Na}_{3} \mathrm{C}_{6}$ $\mathrm{H}_{5} \mathrm{O}_{7}$ ), and $\mathrm{Ca}-\mathrm{P}$ (the residual $+10 \mathrm{~mL}$ $\left.0.5 \mathrm{~mol} \cdot \mathrm{L}^{-1} \mathrm{H}_{2} \mathrm{SO}_{4}\right)$. Soil total $\mathrm{P}$ was digested with concentrated $\mathrm{H}_{2} \mathrm{SO}_{4}+\mathrm{H}_{2} \mathrm{O}_{2}$, and the AP was extracted by $0.03 \mathrm{~mol} \cdot \mathrm{L}^{-1} \mathrm{NH}_{4} \mathrm{~F}+0.03$ mol. $\mathrm{L}^{-1} \mathrm{HCl}$ (Bray and Kurtz, 1945). Samples were extracted by shaking for $2 \mathrm{~h}$. The $\mathrm{P}$ contents of all the extractions were determined by the same method used for plant tissues described previously.

Fractionation of soil Al. Various forms of Al were extracted by sequential extraction procedure with different reagents (Dai et al., 2011; Lu, 2000): For Ex-Al, $1.0 \mathrm{~g}$ soil was mixed with $10 \mathrm{~mL} 1 \mathrm{~mol} \cdot \mathrm{L}^{-1} \mathrm{KCl}$ and shaken for $30 \mathrm{~min}$; for $\mathrm{Ha}-\mathrm{Al}$, the residual was mixed with $10 \mathrm{~mL} 1 \mathrm{~mol} \cdot \mathrm{L}^{-1} \mathrm{NH}_{4} \mathrm{Ac}$ and shaken for $5 \mathrm{~h}$; for In-Al, the residual with $10 \mathrm{~mL}$ $1 \mathrm{~mol} \cdot \mathrm{L}^{-1} \mathrm{HCl}$ was shaken for $1.5 \mathrm{~h}$; for $\mathrm{Hy}$ $\mathrm{Al}$, the residual with $10 \mathrm{~mL} 0.5 \mathrm{~mol} \cdot \mathrm{L}^{-1}$ $\mathrm{NaOH}$ was shaken for $1.5 \mathrm{~h}$; and for Or-Al, $1.0 \mathrm{~g}$ soil was agitated for $2 \mathrm{~h}$ with $10 \mathrm{~mL} 0.1$ $\mathrm{mol} \cdot \mathrm{L}^{-1} \mathrm{Na}_{4} \mathrm{P}_{2} \mathrm{O}_{7} \cdot 10 \mathrm{H}_{2} \mathrm{O}$. Soil total $\mathrm{Al}$ (TAl) was digested with concentrated $\mathrm{H}_{2} \mathrm{SO}_{4}+\mathrm{H}_{2}$ $\mathrm{O}_{2}$. Al contents of all the previous samples were determined following the same method used for analysis of plant tissues.

Pot experiment. One-year-old grafted seedlings with uniform growth were transplanted to $2.5 \mathrm{~L}$ plastic pots $(12 \mathrm{~cm}$ diameter with $18 \mathrm{~cm}$ height) containing $3.2 \mathrm{~kg}$ sand on 27 Apr. 2014. The potted seedlings were

Table 1. Inorganic phosphorus $(\mathrm{P})$ fractions of soil samples taken from Camellia oleifera plantation sites.

\begin{tabular}{|c|c|c|c|c|c|}
\hline Soil $\mathrm{P}$ fraction & Soil zone & Content $\left(\mathrm{mg} \cdot \mathrm{kg}^{-1}\right)$ & Soil P fraction & Soil zone & Content (mg. $\left.\mathrm{kg}^{-1}\right)$ \\
\hline \multirow[t]{2}{*}{$\overline{\mathrm{Fe}-\mathrm{P}}$} & Rhizosphere & $133.08 \pm 22.45 \mathrm{a}^{\mathrm{z}}$ & \multirow[t]{2}{*}{$\mathrm{O}-\mathrm{P}$} & Rhizosphere & $7.24 \pm 1.89 \mathrm{a}$ \\
\hline & $20-40 \mathrm{~cm}$ & $111.37 \pm 20.00 \mathrm{~b}$ & & $20-40 \mathrm{~cm}$ & $6.01 \pm 1.27 \mathrm{~b}$ \\
\hline Total $(\%$ of total $\mathrm{P})$ & & $368.95(38.4 \%)$ & \multicolumn{2}{|c|}{ Total $(\%$ of total $\mathrm{P})$} & $19.99(2.1 \%)$ \\
\hline \multirow{2}{*}{ Al-P } & $0-20 \mathrm{~cm}$ & $98.65 \pm 22.80 \mathrm{~b}$ & \multirow{2}{*}{ AP } & $0-20 \mathrm{~cm}$ & $1.64 \pm 0.70 \mathrm{~b}$ \\
\hline & $20-40 \mathrm{~cm}$ & $87.35 \pm 16.10 b$ & & $20-40 \mathrm{~cm}$ & $1.39 \pm 0.61 \mathrm{c}$ \\
\hline \multicolumn{2}{|l|}{ Total $(\%$ of total $\mathrm{P})$} & $294.81(30.7 \%)$ & \multicolumn{2}{|c|}{ Total $(\%$ of total $\mathrm{P})$} & $4.96(0.5 \%)$ \\
\hline Total (\% of total P) & & $37.64(3.9 \%)$ & \multicolumn{2}{|c|}{ Total (\% of total P) } & $960.64(100 \%)$ \\
\hline
\end{tabular}

${ }^{\mathrm{z}}$ Data presented are mean \pm SD. Different letters in the same column within each type of $\mathrm{P}$ indicate significant difference at $P \leq 0.05$ (Duncan's multiple range tests). Phosphorus Fractionations were determined by the sequential extraction procedure (Chang and Jackson, 1957 ): $\mathrm{Al}-\mathrm{P}: 0.5 \mathrm{~g}$ soil $+10 \mathrm{~mL} 0.5 \mathrm{~mol} \cdot \mathrm{L}^{-1} \mathrm{NH}_{4} \mathrm{~F}$; Fe-P: the residual $+10 \mathrm{~mL} 0.1 \mathrm{~mol} \cdot \mathrm{L}^{-1} \mathrm{NaOH}$; O-P: the residual $+10 \mathrm{~mL} 0.3 \mathrm{~mol} \cdot \mathrm{L}^{-1} \mathrm{Na}_{3} \mathrm{C}_{6} \mathrm{H}_{5} \mathrm{O}_{7}$; Ca-P: the residual $+10 \mathrm{~mL} 0.5 \mathrm{~mol} \cdot \mathrm{L}^{-1} \mathrm{H}_{2} \mathrm{SO}_{4}$. Total P: Soil total P; AP: Soil available P.

Table 2. Aluminum fractions of soil samples taken from Camellia oleifera plantation sites.

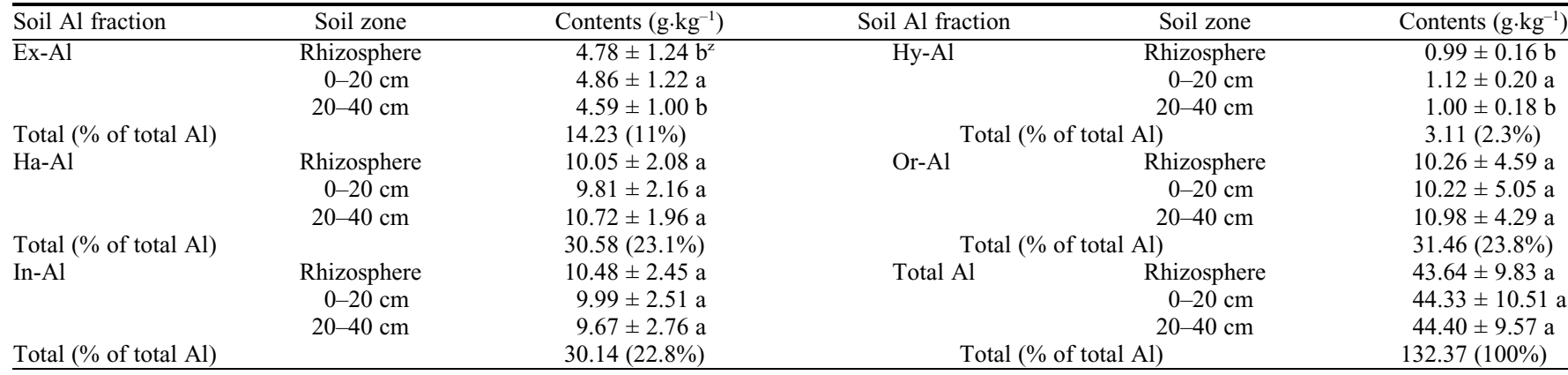

${ }^{\mathrm{z}}$ Data presented are mean $\pm \mathrm{SD}$. Different letters in the same column within each type of $\mathrm{Al}$ indicate significant difference at $P \leq 0.05$. Aluminum forms were extracted by sequential extraction procedure (Dai et al., 2011; Lu, 2000): Ex-Al: $1.0 \mathrm{~g}$ soil was mixed with $10 \mathrm{~mL} 1 \mathrm{~mol} \cdot \mathrm{L}^{-1} \mathrm{KCl}$ and shaken for $30 \mathrm{~min}$; Ha-Al: the residual mixed with $10 \mathrm{~mL} 1 \mathrm{~mol} \cdot \mathrm{L}^{-1} \mathrm{NH}_{4} \mathrm{Ac}$ were shaken for $5 \mathrm{~h}$; In-Al: the residual with $10 \mathrm{~mL} 1 \mathrm{~mol} \cdot \mathrm{L}^{-1} \mathrm{HCl}$ were shaken for $1.5 \mathrm{~h}$; Hy-Al: the residual with $10 \mathrm{~mL} 0.5 \mathrm{~mol} \cdot \mathrm{L}^{-1} \mathrm{NaOH}$ were shaken for $1.5 \mathrm{~h}$; Or-Al: $1.0 \mathrm{~g}$ soil were agitated for $2 \mathrm{~h}$ with $10 \mathrm{~mL} 0.1 \mathrm{~mol} \cdot \mathrm{L}^{-1} \mathrm{Na}_{4} \mathrm{P}_{2} \mathrm{O}_{7} \cdot 10 \mathrm{H}_{2} \mathrm{O}$. 
grown outdoors and protected from rainfall by a plastic canopy. Four treatments of different combinations of $\mathrm{P}$ and $\mathrm{Al}$ concentrations were created by adding $\mathrm{Al}$ or $\mathrm{P}$ to Hoagland-Arnon solution: $\mathrm{Al}^{-} \mathrm{P}^{-}$: no $\mathrm{Al}$ or $\mathrm{P}$ added; $\mathrm{Al}^{-} \mathrm{P}^{+}$: no $\mathrm{Al}$ and $1 \mathrm{~mol} \mathrm{P} \cdot \mathrm{L}^{-1}$ added; $\mathrm{Al}^{+} \mathrm{P}^{-}: 2 \mathrm{mmol} \mathrm{Al} \cdot \mathrm{L}^{-1}$ and no $\mathrm{P}$ added; and $\mathrm{Al}^{+} \mathrm{P}^{+}: 2 \mathrm{mmol} \mathrm{Al} \cdot \mathrm{L}^{-1}$ and $1 \mathrm{~mol} \mathrm{P} \cdot \mathrm{L}^{-1}$ added (all other elements were kept unchanged). Plants were irrigated with $200 \mathrm{~mL}$ treatment solutions every $3 \mathrm{~d}$ starting from $30 \mathrm{Apr}$. 2014. The source of $\mathrm{P}$ was $\mathrm{KH}_{2} \mathrm{PO}_{4}$, and the $\mathrm{K}^{+}$in the nutrient solution was adjusted by $\mathrm{KCl}$. Al was provided by $\mathrm{AlCl}_{3}$. The $\mathrm{pH}$ of the treatment solutions was adjusted to 5.5 with $0.5 \% \mathrm{Ca}$ $(\mathrm{OH})_{2}$ or $\mathrm{H}_{2} \mathrm{SO}_{4}$. Additional 100-mL distilled water was applied in the evenings on hot days to insure sufficient moisture. There were five replicates in each treatment, and the pots were arranged in a completely randomized design. The seedlings were harvested on 27 Aug. 2014.
Total plant dry weight (DW) was obtained after oven dried at $65^{\circ} \mathrm{C}$ to a constant weight. The dried plants (whole plants, including stems, leaves, and roots) were analyzed for $\mathrm{P}$ and $\mathrm{Al}$ contents using the same methods mentioned previously.

Statistical analysis. Data from all sample sites were pooled because no site differences were found. One-way analysis of variance (ANOVA) was performed, when significant, Duncan's multiple range tests were followed to distinguish the differences in $\mathrm{P}$ and $\mathrm{Al}$ fractionation among the three soil sample layers. Correlation analysis was performed using SPSS for Windows V17.0. All graphs were made by Origin 8.5.

\section{Results}

Fractionation of soil $P$. In all three types of soil samples, Fe-P contents were the highest,

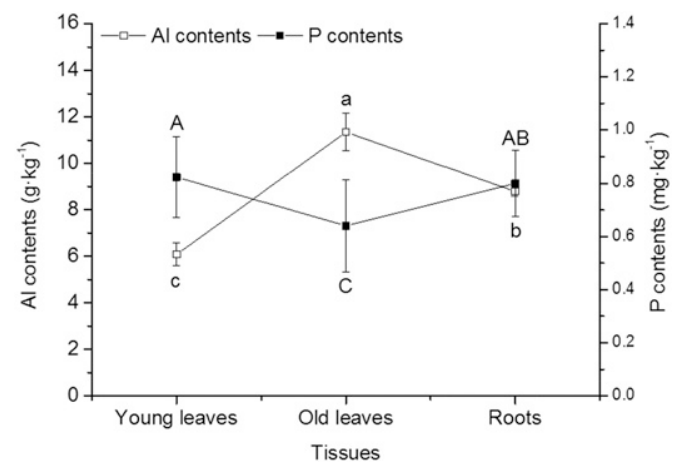

Fig. 2. Phosphorus $(\mathrm{P})$ and aluminum $(\mathrm{Al})$ contents in tissue samples of Camellia oleifera sampled from the plantation. Data points with different letters indicate significant difference at $P \leq 0.05$. Upper case for $\mathrm{P}$ contents and lower case for $\mathrm{Al}$ contents. followed by Al-P, accounted for $38 \%$ and $31 \%$ of total $\mathrm{P}$, respectively (Table 1). Ca-P and O-P accounted for $3.9 \%$ and $2 \%$ of total $\mathrm{P}$, respectively, whereas AP was only $0.5 \%$ of total P. Numerically, the rhizosphere soil contained the highest $\mathrm{P}$ of all forms. The ANOVA analysis showed that for Fe-P, Ca-P, and O-P, there was no difference between rhizosphere and $0-20 \mathrm{~cm}$ and between $0-20 \mathrm{~cm}$ and 20 $40 \mathrm{~cm}$ soils. For Al-P, no significant difference was found between $0-20 \mathrm{~cm}$ and $20-40 \mathrm{~cm}$ soils. The total $\mathrm{P}$ content at $0-20 \mathrm{~cm}$ was significantly higher than that at $20-40 \mathrm{~cm}$ soils, whereas no significant difference was found between rhizosphere and $0-20 \mathrm{~cm}$ soils. The content of AP in rhizosphere soil was significantly higher than that of the nonrhizosphere soils, and the AP in $0-20 \mathrm{~cm}$ was higher than that of $20-40 \mathrm{~cm}$ soils.

Fractionation of soil Al. For Ha-Al, In-Al, Or-Al, and total $\mathrm{Al}$, no differences were observed among rhizosphere and other soil zones (Table 2). The contents of Ha-Al, In-Al, and Or-Al were similar and each accounted for $\approx 23 \%$ of total $\mathrm{Al}$, whereas Ex-Al accounted for $11 \%$, and $\mathrm{Hy}-\mathrm{Al}$ accounted for $2.3 \%$ of total $\mathrm{Al}$. The contents of Ex-Al and Hy-Al in the soil zone of 0-20 cm were greater than that of the rhizosphere and $20-40 \mathrm{~cm}$, and no significant difference was observed between rhizosphere and $20-40 \mathrm{~cm}$ soils

$P$ and Al contents in plant tissues. The $\mathrm{P}$ contents in roots and young leaves were 0.799 and $0.823 \mathrm{mg} \cdot \mathrm{kg}^{-1}$, respectively, and no difference was found between them (Fig. 2). However, they were significantly higher than the $\mathrm{P}$ content in the old leaves, which was 0.639 $\mathrm{mg} \cdot \mathrm{kg}^{-1}$. On the contrary, the highest $\mathrm{Al}$ content $\left(11.345 \mathrm{~g} \cdot \mathrm{kg}^{-1}\right)$ was found in the old

Table 3. Correlations ( $r$ values) between phosphorus $(\mathrm{P})$ content of Camellia oleifera plant tissues and soil $\mathrm{P}$ fractions.

\begin{tabular}{|c|c|c|c|c|c|c|c|}
\hline Soil zone & Tissues & Al-P & Fe-P & O-P & Ca-P & AP & $\mathrm{TP}$ \\
\hline \multirow{3}{*}{ Rhizosphere } & Roots & 0.3837 & 0.0690 & -0.0889 & -0.1272 & $0.509^{* z}$ & 0.0851 \\
\hline & Young leaves & 0.1322 & 0.2397 & 0.1860 & 0.1275 & -0.3369 & 0.2129 \\
\hline & Old leaves & 0.0924 & 0.1570 & 0.1095 & 0.0028 & -0.2625 & 0.1437 \\
\hline \multirow{2}{*}{$0-20 \mathrm{~cm}$} & Young leaves & 0.0520 & -0.0210 & 0.1420 & 0.0280 & -0.4190 & 0.0160 \\
\hline & Old leaves & 0.1140 & 0.0410 & 0.1680 & 0.1080 & -0.3080 & 0.0720 \\
\hline \multirow[t]{2}{*}{$20-40 \mathrm{~cm}$} & Roots & 0.0233 & -0.0326 & -0.0274 & 0.0760 & 0.1294 & 0.0605 \\
\hline & Young leaves & 0.0680 & 0.0512 & 0.1738 & 0.0744 & -0.3380 & 0.0692 \\
\hline
\end{tabular}

Z* indicates significant at $P \leq 0.05$. Phosphorus Fractionations were determined by the sequential extraction procedure (Chang and Jackson, 1957$)$ : Al-P: $0.5 \mathrm{~g}$ soil $+10 \mathrm{~mL}$ $0.5 \mathrm{~mol} \cdot \mathrm{L}^{-1} \mathrm{NH}_{4} \mathrm{~F}$; Fe-P: the residual $+10 \mathrm{~mL} 0.1 \mathrm{~mol} \cdot \mathrm{L}^{-1} \mathrm{NaOH}$; O-P: the residual $+10 \mathrm{~mL} 0.3 \mathrm{~mol} \cdot \mathrm{L}^{-1} \mathrm{Na}_{3} \mathrm{C}_{6} \mathrm{H}_{5} \mathrm{O}_{7}$; Ca-P: the residual $+10 \mathrm{~mL} 0.5 \mathrm{~mol} \cdot \mathrm{L}^{-1} \mathrm{H}_{2} \mathrm{SO}_{4}$. Total P: Soil total P; AP: Soil available P.

Table 4. Correlations ( $r$ values) between aluminum (Al) contents of Camellia oleifera plant tissues and soil $\mathrm{Al}$ fractions.

\begin{tabular}{|c|c|c|c|c|c|c|c|}
\hline Soil zone & Tissues & Ex-Al & $\mathrm{Ha}-\mathrm{Al}$ & Hy-Al & In-Al & Or-Al & $\mathrm{T}-\mathrm{Al}$ \\
\hline \multirow[t]{2}{*}{ Rhizosphere } & Roots & $0.3412^{* z}$ & 0.1832 & -0.3897 & -0.1123 & 0.0851 & 0.2631 \\
\hline & Old leaves & 0.3495 & 0.2646 & -0.3127 & $0.552^{* *}$ & 0.2166 & $0.625 * *$ \\
\hline \multirow[t]{2}{*}{$0-20 \mathrm{~cm}$} & Roots & 0.3115 & 0.3182 & -0.2656 & -0.1613 & 0.0897 & 0.2285 \\
\hline & Old leaves & 0.3614 & 0.2571 & -0.1356 & $0.539 * *$ & 0.3368 & $0.666^{* *}$ \\
\hline \multirow[t]{2}{*}{$20-40 \mathrm{~cm}$} & Roots & 0.3294 & 0.2664 & -0.2874 & -0.2066 & 0.0105 & 0.2330 \\
\hline & Young leaves & $0.465^{*}$ & $0.476^{*}$ & -0.4172 & $0.502 *$ & 0.4194 & $0.621 * *$ \\
\hline
\end{tabular}

z*,** indicates significant at $P \leq 0.05$ or $P \leq 0.01$. Aluminum forms were extracted by sequential extraction procedure (Dai et al., 2011; Lu, 2000): Ex-Al: $1.0 \mathrm{~g}$ soil was mixed with $10 \mathrm{~mL} 1 \mathrm{~mol} \cdot \mathrm{L}^{-1} \mathrm{KCl}$ and shaken for $30 \mathrm{~min}$; Ha-Al: the residual mixed with $10 \mathrm{~mL} 1 \mathrm{~mol} \cdot \mathrm{L}^{-1} \mathrm{NH}_{4} \mathrm{Ac}$ were shaken for $5 \mathrm{~h}$; In-Al: the residual with $10 \mathrm{~mL} 1 \mathrm{~mol} \cdot \mathrm{L}^{-1} \mathrm{HCl}$ were shaken for $1.5 \mathrm{~h}$; Hy-Al: the residual with $10 \mathrm{~mL} 0.5 \mathrm{~mol} \cdot \mathrm{L}^{-1} \mathrm{NaOH}$ were shaken for $1.5 \mathrm{~h}$; Or- $\mathrm{Al}: 1.0 \mathrm{~g}$ soil were agitated for $2 \mathrm{~h}$ with $10 \mathrm{~mL} 0.1 \mathrm{~mol} \cdot \mathrm{L}^{-1} \mathrm{Na}_{4} \mathrm{P}_{2} \mathrm{O}_{7} \cdot 10 \mathrm{H}_{2} \mathrm{O}$. 
Table 5. Correlation ( $r$ values) between phosphorus (P) and aluminum (Al) fractions in different soil zones of Camellia oleifera plantations.

\begin{tabular}{|c|c|c|c|c|c|c|c|}
\hline $\mathrm{P}$ fraction & Soil layer & Ex-Al & Ha-Al & $\mathrm{Hy}-\mathrm{Al}$ & In-Al & Or-Al & T-Al \\
\hline \multirow[t]{2}{*}{$\overline{\mathrm{Al}-\mathrm{P}}$} & Rhizosphere & $0.3279^{* \mathrm{z}}$ & 0.0519 & 0.1964 & -0.0215 & -0.3205 & -0.0381 \\
\hline & $20-40 \mathrm{~cm}$ & 0.0549 & -0.1388 & 0.0539 & 0.1043 & -0.0868 & -0.1510 \\
\hline \multirow[t]{2}{*}{$\mathrm{Fe}-\mathrm{P}$} & Rhizosphere & 0.3545 & -0.0567 & 0.2758 & 0.0238 & -0.3291 & -0.1383 \\
\hline & $20-40 \mathrm{~cm}$ & 0.0488 & -0.0744 & 0.0758 & 0.0903 & -0.0229 & -0.1431 \\
\hline \multirow[t]{2}{*}{$\mathrm{O}-\mathrm{P}$} & Rhizosphere & 0.2118 & -0.2056 & $0.503 *$ & 0.0079 & -0.3337 & -0.1084 \\
\hline & $0-20 \mathrm{~cm}$ & 0.2499 & -0.1342 & 0.1855 & 0.0166 & -0.3855 & -0.2792 \\
\hline \multirow{2}{*}{ Ca-P } & $0-20 \mathrm{~cm}$ & 0.2985 & -0.0426 & 0.2232 & 0.0334 & -0.1867 & -0.0996 \\
\hline & $20-40 \mathrm{~cm}$ & 0.0820 & -0.0095 & 0.1090 & 0.0549 & 0.1427 & -0.1082 \\
\hline \multirow[t]{3}{*}{$\mathrm{AP}$} & Rhizosphere & 0.6533 & 0.0287 & -0.1034 & 0.0449 & $0.515^{*}$ & 0.0574 \\
\hline & $0-20 \mathrm{~cm}$ & 0.3809 & 0.2006 & -0.3620 & 0.1542 & $0.601 * *$ & 0.2950 \\
\hline & $20-40 \mathrm{~cm}$ & 0.2635 & -0.0765 & -0.3601 & 0.1073 & 0.3484 & 0.2378 \\
\hline \multirow[t]{2}{*}{$\mathrm{TP}$} & Rhizosphere & 0.2760 & -0.2192 & 0.1783 & 0.1027 & -0.5140 & -0.1538 \\
\hline & $0-20 \mathrm{~cm}$ & 0.1357 & -0.1105 & 0.2796 & 0.0520 & -0.3558 & -0.1818 \\
\hline
\end{tabular}

z*, ** indicates significant at $P \leq 0.05$ or $P \leq 0.01$. Aluminum forms were extracted by sequential extraction procedure (Dai et al., 2011; Lu, 2000): Ex-Al: $1.0 \mathrm{~g}$ soil was mixed with $10 \mathrm{~mL} 1 \mathrm{~mol} \cdot \mathrm{L}^{-1} \mathrm{KCl}$ and shaken for $30 \mathrm{~min}$; Ha-Al: the residual mixed with $10 \mathrm{~mL} 1 \mathrm{~mol} \cdot \mathrm{L}^{-1} \mathrm{NH}_{4} \mathrm{Ac}$ were shaken for $5 \mathrm{~h}$; In-Al: the residual with $10 \mathrm{~mL} 1 \mathrm{~mol} \cdot \mathrm{L}^{-1} \mathrm{HCl}$ were shaken for $1.5 \mathrm{~h}$; Hy-Al: the residual with $10 \mathrm{~mL} 0.5 \mathrm{~mol} \cdot \mathrm{L}^{-1} \mathrm{NaOH}$ were shaken for $1.5 \mathrm{~h}$; Or-Al: $1.0 \mathrm{~g}$ soil were agitated for $2 \mathrm{~h}$ with $10 \mathrm{~mL} 0.1 \mathrm{~mol} \cdot \mathrm{L}^{-1} \mathrm{Na}_{4} \mathrm{P}_{2} \mathrm{O}_{7} \cdot 10 \mathrm{H}_{2} \mathrm{O}$.

leaves, followed by roots and the young leaves with 8.784 and $6.085 \mathrm{~g} \cdot \mathrm{kg}^{-1}$, respectively.

Relationship between plant $P$ and $A l$ contents and soil $P$ and Al fractions. Correlation analyses showed that $P$ content in roots was positively correlated with AP in rhizosphere soil $(r=0.509, P=0.04)$. No other significant correlation between different $\mathrm{P}$ forms in the soil and plant tissues was observed (Table 3 ). More significant correlations were found between Al contents in plant tissues and soil Al fractions (Table 4). In the rhizosphere zone, positive correlations were observed between Al contents in young leaves and soil Ex-Al, Ha-Al, In-Al, and T-Al; between $\mathrm{Al}$ content in roots and soil Ex-Al; and between $\mathrm{Al}$ contents in old leaves and soil In-Al and T-Al. Similarly, Al contents in young leaves had correlations with soil ExAl, Ha-Al, In-Al, and T-Al, but not with Hy$\mathrm{Al}$, in the $0-20 \mathrm{~cm}$ and $20-40 \mathrm{~cm}$ soil zones. Also, Al contents in roots did not have any correlation with any $\mathrm{Al}$ fraction of soils at $0-20 \mathrm{~cm}$ and $20-40 \mathrm{~cm}$.

Relationship between soil $P$ and $A l$ fractions. Significant correlations were found between Al-P and Ex-Al, between O-P and $\mathrm{Hy}-\mathrm{Al}$ in the rhizosphere, and between AP and Or-Al in the rhizosphere and 0-20 cm soils. All other correlation analyses were not significant (Table 5).

Growth of $C$. oleifera under different $P$ and Al regimes. The pot experiment showed that the supplement of $\mathrm{P}$ or $\mathrm{Al}$ or both significantly increased the plant biomass (Fig. 3). The DW was the highest when both $\mathrm{P}$ and $\mathrm{Al}$ were added to the nutrient solution $\left(\mathrm{Al}^{+} \mathrm{P}^{+}\right)$and the lowest when neither $\mathrm{P}$ nor $\mathrm{Al}$ was added $\left(\mathrm{Al}^{-} \mathrm{P}^{-}\right)$. No difference in the DW was found when either $\mathrm{P}$ or Al was added to the solution. The significantly higher DW of $\mathrm{P}^{+} \mathrm{Al}^{+}$treatment indicates a synergistic effect between $\mathrm{P}$ and $\mathrm{Al}$.

Adding $\mathrm{P}$ or $\mathrm{Al}$ alone significantly increased plant $\mathrm{P}$ or $\mathrm{Al}$ content compared with no addition ( $\mathrm{Al}^{-} \mathrm{P}-$ ) (Fig. 4). When both $\mathrm{P}$ and $\mathrm{Al}$ were added $\left(\mathrm{Al}^{+} \mathrm{P}^{+}\right)$, the plant $\mathrm{P}$ and $\mathrm{Al}$ contents

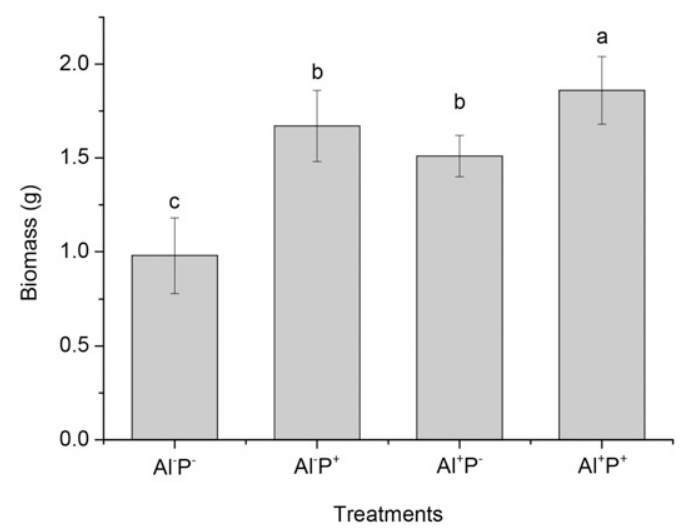

Fig. 3. The biomass (dry weight) of Camellia oleifera grown in a pot and irrigated with solutions containing different aluminum $(\mathrm{Al})$ and phosphorus $(\mathrm{P})$ concentrations. Bars with different letters indicate significant difference at $P \leq 0.05$. $\mathrm{Al}^{-} \mathrm{P}^{-}$: no $\mathrm{Al}$ or $\mathrm{P}$ added; $\mathrm{Al}^{-} \mathrm{P}^{+}$: no $\mathrm{Al}$ and $1 \mathrm{~mol} \mathrm{P} / \mathrm{L}$ added; $\mathrm{Al}^{+} \mathrm{P}^{-}: 2 \mathrm{mmol} \mathrm{Al} / \mathrm{L}$ and no $\mathrm{P}$ added; and $\mathrm{Al}^{+} \mathrm{P}^{+}: 2 \mathrm{mmol} \mathrm{Al} / \mathrm{L}$ and $1 \mathrm{~mol} \mathrm{P} / \mathrm{L}$ added.

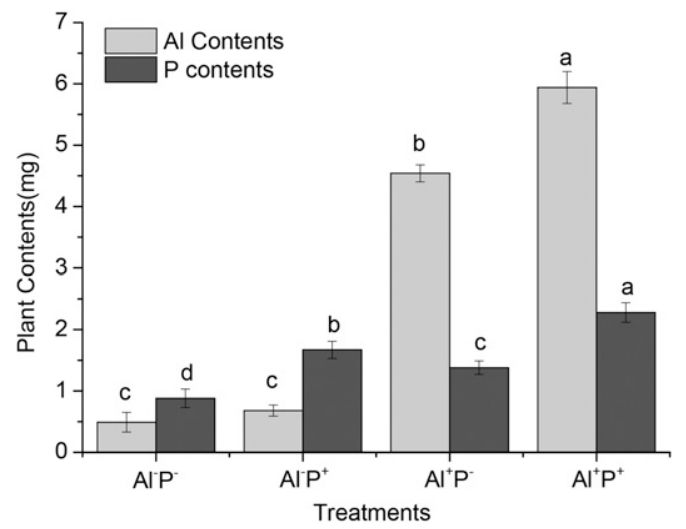

Fig. 4. Phosphorus (P) and aluminum (Al) contents in Camellia oleifera grown in a pot and irrigated with solutions containing different $\mathrm{Al}$ and $\mathrm{P}$ concentrations. Within an element ( $\mathrm{Al}$ or $\mathrm{P}$ ), bars with different letters indicate significant difference at $P \leq 0.05$. $\mathrm{Al}^{-} \mathrm{P}-$ : no $\mathrm{Al}$ or $\mathrm{P}$ added; $\mathrm{Al}^{-} \mathrm{P}^{+}$: no $\mathrm{Al}$ and $1 \mathrm{~mol} \mathrm{P} / \mathrm{L}$ added; $\mathrm{Al}^{+} \mathrm{P}^{-}: 2 \mathrm{mmol} \mathrm{Al} / \mathrm{L}$ and no $\mathrm{P}$ added; and $\mathrm{Al}^{+} \mathrm{P}^{+}: 2 \mathrm{mmol} \mathrm{Al} / \mathrm{L}$ and $1 \mathrm{~mol} \mathrm{P} / \mathrm{L}$ added.

were significantly higher than when $\mathrm{P}\left(\mathrm{Al}^{-} \mathrm{P}^{+}\right)$ or $\mathrm{Al}\left(\mathrm{Al}^{+} \mathrm{P}^{-}\right)$were added alone at the same concentrations. This result indicates that the interaction between $\mathrm{P}$ and $\mathrm{Al}$ promotes plant absorption of both elements.

\section{Discussion}

At low soil pH (acidic soil), Al becomes more soluble in the soil solution and thus becomes toxic to living organisms (Zheng, 
2010). $\mathrm{P}$ can strongly react with $\mathrm{Al}$ oxide and becomes unavailable to plants causing $\mathrm{P}$ deficiency (Kochian et al., 2004; Shen et al., 2011). Therefore, $\mathrm{P}$ deficiency and $\mathrm{Al}$ toxicity have long been considered as two concurrent limiting factors for plant growth and crop production in acidic soils (Yu et al., 2016). C. oleifera is mainly cultivated in red acidic soils and faces strong challenges of $\mathrm{P}$ deficiency and high concentration of Al. However, the growth and fruit yield of $C$. oleifera seem not suppressed (He et al., 2010; Yuan et al., 2013b; Zeng et al., 2011). Observations of $C$. oleifera suggest that this plant may have evolved adaptive mechanisms to $\mathrm{Al}$ toxicity and $\mathrm{P}$ deficiency in red acidic soils (Shen et al., 2011; Zhang et al., 1997). C. oleifera has been proven to be a Pefficient and Al-hyperaccumulator plant (Zeng et al., 2011).

Our study found that all the $\mathrm{P}$ fractions in top soils (rhizosphere and $0-20 \mathrm{~cm}$ zone) were higher than that of subsoil (20-40 cm zone), which could be due to surface application of $P$ fertilizer, a common practice in the plantations (Caione et al., 2015). Because $\mathrm{Al}$ is abundant in the acidic soil and $C$. oleifera plants absorbed Al more than the plants needed, which caused higher concentrations in older leaves. This is a similar situation to high soil salinity condition when plants absorbed more sodium and chloride in older leaves than in young leaves (Niu and Cabrera, 2010). On the other hand, the AP content in the acidic soil was very low, which may cause a lower P concentration in the older leaves.

The Fe-P and Al-P were the major fractions of $\mathrm{P}$ in the red acidic soil and were over $65 \%$ of total $\mathrm{P}$ in samples of rhizosphere, 0 20 and $20-40 \mathrm{~cm}$ soil zones. This suggests that these two fractions (Fe-P, Al-P) may be the main source of insoluble $\mathrm{P}$ absorbed by $C$. oleifera, which can explain a previous observation that adding $\mathrm{AlPO}_{4}$ to red acidic soils effectively increased the growth of C. oleifera seedlings (Yuan et al., 2013b). Al-P extracted by $\mathrm{NH}_{4} \mathrm{~F}$ and $\mathrm{HCl}$ are considered as labile forms of Hedley fractionation (Caione et al., 2015). This is why that the relatively strong positive relationship between Al-P and root P was observed, especially in rhizosphere in the current study. Our results also suggest that $C$. oleifera plants have some adaptive mechanisms to dissolve Al-P to obtain sufficient P. As a result, $\mathrm{Al}^{3+}$ is released to soil solution and absorbed by soil particle or organic matters, which leads to the an increase in Ex-Al. This mechanism not only provides a theoretical basis for $C$. oleifera as a hyperaccumulator (Zeng et al., 2011) but also raises a question of whether $\mathrm{Al}$ and $\mathrm{P}$ interactively affect the growth and development of $C$. oleifera.

In the practice of $C$. oleifera cultivation, increasing soil $\mathrm{pH}$ by adding lime could alleviate $\mathrm{Al}$ toxicity ( $\mathrm{He}$ et al., 2010), and the coexistence of high $\mathrm{Al}$ and low $\mathrm{P}$ does not limit plant growth and production (Chen et al., 2008). Our pot experiment showed that the addition of $\mathrm{Al}$ or $\mathrm{P}$ alone increased the plant growth and contents of $\mathrm{P}$, whereas adding both $\mathrm{Al}$ and $\mathrm{P}$ led to a significant synergistic effect with higher plant growth and contents of both $\mathrm{P}$ and Al. Therefore, the current study further confirmed the fact that C. oleifera plants are well-adapted to high $\mathrm{Al}$ and low P conditions (Yuan et al., 2013b). Future studies should focus on understanding the rhizosphere processes of insoluble Al-P and the synergistic absorption mechanism of $\mathrm{P}$ and Al. These studies will ultimately reveal the adaptation mechanisms of $C$. oleifera to low-P and high-Al conditions.

The current study found that Fe-P and Al-P were the main components of soil $\mathrm{P}$ in the red acidic soils of $C$. oleifera plantations. Ex-Al and AP contents in the rhizosphere soil were significantly higher than nonrhizosphere soils. The $\mathrm{P}$ content in roots was positively associated with AP, Al-P, and Ex-Al in the rhizosphere. Adding both $\mathrm{Al}$ and $\mathrm{P}$ significantly increased $\mathrm{Al}$ and $\mathrm{P}$ contents in plants and plant growth. More importantly, $\mathrm{Al}$ is a beneficial element to $C$. oleifera suggesting that it has an adaptive mechanism to use Al-P in the red acidic soil.

\section{Literature Cited}

Álvarez, E., M.J. Fernández-Sanjurjo, A. Núñez, N. Seco, and G. Corti. 2012. Aluminium fractionation and speciation in bulk and rhizosphere of a grass soil amended with mussel shells or lime. Geoderma 173-174:322-329.

Barcelo, J. and C. Poschenrieder. 2002. Fast root growth responses, root exudates, and internal detoxification as clues to the mechanisms of aluminium toxicity and resistance: A review. Environ. Exp. Bot. 48:75-92.

Bray, R. and L. Kurtz. 1945. Determination of total organic and available forms of phosphorus in soils. Soil Sci. 59:39-46.

Caione, G., R.M. Prado, C.N.S. Campos, M. Rodrigues, P.S. Pavinato, and F.B. Agostinho 2015. Phosphorus fractionation in soil cultivated with sugarcane fertilized by filter cake and phosphate sources. Commun. Soil Sci. Plant Anal. 46:2449-2459.

Chang, S. and M. Jackson. 1957. Fractionation of soil phosphorus. Soil Sci. 84:133-144.

Chen, R.F., R.F. Shen, P. Gu, H.Y. Wang, and X.H. $\mathrm{Xu}$. 2008. Investigation of aluminum-tolerant species in acid soils of south China. Commun. Soil Sci. Plant Anal. 39:1493-1506.

Dai, Q., N. Ae, T. Suzuki, M. Rajkumar, S. Fukunaga, and N. Fujitake. 2011. Assessment of potentially reactive pools of aluminum in Andisols using a five-step sequential extraction procedure. Soil Sci. Plant Nutr. 57:500-507.

He, G., J. Zhang, X. Hu, and J. Wu. 2010. Effect of aluminum toxicity and phosphorus deficiency on the growth and photosynthesis of oil tea (Camellia oleifera Abel.) seedlings in acidic red soils. Acta Physiol. Plant. 33:1285-1292.

Iqbal, M.T. 2014. Phosphorus alleviates aluminum toxicity in Al-sensitive wheat seedlings. Commun. Soil Sci. Plant Anal. 45:437-450.

Kochian, L.V. 1995. Cellular mechanisms of aluminum toxicity and resistance in plants. Annu. Rev. Plant Physiol. Plant Mol. Biol. 46:237-260.

Kochian, L., O.A. Hoekenga, and M.A. Piñeros 2004. How do crop plants tolerate acid soils? Mechanisms of aluminum tolerance and phosphorous efficiency. Annu. Rev. Plant Biol. 55:459-493.
Li, Y., R. Yang, R. Gao, H. Wei, A. Chen, and Y. Li. 2015. Effects of long-term phosphorus fertilization and straw incorporation on phosphorus fractions in subtropical paddy soil. J. Integr. Agr. 14:365-373.

Liao, H., H. Wan, J. Shaff, X. Wang, X. Yan, and L. Kochian. 2006. Phosphorus and aluminum interactions in soybean in relation to aluminum tolerance. Exudation of specific organic acids from different regions of the intact root system. Plant Physiol. 141:674-684.

Ligaba, A., M. Yamaguchi, H. Shen, T. Sasaki, Y. Yamamoto, and H. Matsumoto. 2004. Phosphorus deficiency enhances plasma membrane $\mathrm{H}^{+}$-ATPase activity and citrate exudation in greater purple lupin (Lupinus pilosus). Funct. Plant Biol. 31:1075-1083.

Liu, B., C. Luo, X. Li, L. Gray, F. Zhang, M. Liu, J. $\mathrm{Ju}$, and B. Lei. 2014. Research on the threshold of aluminum toxicity and the alleviation effects of exogenous calcium, phosphorus, and nitrogen on the growth of chinese fir seedlings under aluminum stress. Commun. Soil Sci. Plant Anal. 45:126-139.

Lu, R. 2000. Agricultural soil chemical analysis method. China Agri. Sci. Tech. Press, Peking, China.

Maejima, E., T. Watanabe, M. Osaki, and T. Wagatsuma. 2014. Phosphorus deficiency enhances aluminum tolerance of rice (Oryza sativa) by changing the physicochemical characteristics of root plasma membranes and cell walls. J. Plant Physiol. 171:9-15.

Nieuwenburg, C.J.V. and G. Uitenbroek. 1948. On the detection of aluminium by means of aluminon. Anal. Chim. Acta 2:88-91.

Niu, G. and R.I. Cabrera. 2010. Growth and physiological responses of landscape plants to saline water irrigaton - A review. HortScience 45:1605-1609.

Shen, J., L. Yuan, J. Zhang, H. Li, Z. Bai, X. Chen, W. Zhang, and F. Zhang. 2011. Phosphorus dynamics: From soil to plant. Plant Physiol. 156:997-1005.

Yi, M., H. Yi, H. Li, and L. Wu. 2010. Aluminum induces chromosome aberrations, micronuclei, and cell cycle dysfunction in root cells of Vicia faba. Environ. Toxicol. 25:124-129.

Yu, W., Q. Kan, J. Zhang, and Q. Chen. 2016. Role of the plasma membrane $\mathrm{H}^{+}$-ATPase in the regulation of organic acid exudation under aluminum toxicity and phosphorus deficiency. Plant Signal. Behav. 11:e1106660.

Yuan, J., X. Tan, S. Ye, N. Zhou, and B. Shi. 2013a. The organic acids in root exudates of oiltea and its role in mobilization of sparingly soluble phosphate in red soil. J. Chem. Pharm. Res. 5:572-577.

Yuan, J., X. Tan, D. Yuan, X. Zhang, S. Ye, and J.Q Zhou. 2013b. Effect of phosphates on the growth, photosynthesis, and P content of oil tea in acidic red soils. J. Sustain. For. 32:594-604.

Zeng, Q., R. Chen, X. Zhao, H. Wang, and R. Shen. 2011. Aluminium uptake and accumulation in the hyperaccumulator Camellia oleifera Abel. Pedosphere 21:358-364.

Zhang, F.S., J. Ma, and Y.P. Cao. 1997. Phosphrous deficiency enhances root exudation of lowmolecular weight organic acids and utilization of sparingly soluble inorganic phosphates by radish (Raghanus satiuvs L.) and rape (Brassica napus L.) plants. Plant Soil 196:261-264.

Zheng, S. 2010. Crop production on acidic soils: Overcoming aluminium toxicity and phosphorus deficiency. Ann. Bot. 106:183-184.

Zhuang, R. 2008. Camellia oleifera in China, 2nd ed. For. Press of China, Beijing, China. 